\title{
“AND AFRICA WILL BE SAVED!”? NADENKE OOR DIE KERK, DIE SENDING EN DIE NOOD VAN SUB-SAHARA-AFRIKA
}

\author{
P. Verster ${ }^{1}$ \\ ABSTRACT

\section{“AND AFRICA WILL BE SAVED!”? THOUGHTS ON THE CHURCH, MISSION AND THE NEED OF SUB-SAHARAN AFRICA}

Livingstone (1813-1873) with his emphasis on "Christianity, civilisation, commerce" had high expectations that Western influence would lead to total new conditions in Africa and the end of slave trade. Ludwig Krapf (1810-1881) was very sceptical concerning Western influence and of opinion that it would only lead to foreign solutions and new oppression in Africa. These two views are still present in the debate today. Through the years different exponents suggested that Africa should be given the opportunity to develop on its own while others suggested that massive help from developed countries was necessary. This article concurs with the views of Attie van Niekerk and suggests that elaborate developments will not succeed, but that the church should build up families as cornerstones of the community. In this sense Christ and his Kingdom should be proclaimed as the essence of mission.

\section{INLEIDING}

Die kerk in Afrika beleef 'n moeilike tyd, wat die vraag laat ontstaan hoe 'n mens moet reageer op hierdie krisisse en uitdagings waarvoor die kerk in Afrika, en veral Afrika suid van die Sahara, te staan kom. Reeds aan die begin van grootskaalse Westerse betrokkenheid by Afrika het die vraag hoe die Westerse wêreld en ook veral die kerk by Afrika betrokke moet wees, sterk na vore gekom. Een van die eerste essensiële vrae was dan ook of die Westerse betrokkenheid tot totale nuwe ontwikkeling in Afrika moes lei, en of Afrika eintlik steeds op homself aangewese moes bly. Hierdie artikel wil die verskillende benade-

1 Prof. P. Verster, Hoof: Departement Sendingswetenskap, Fakulteit Teologie, Universiteit van die Vrystaat, Posbus 339, Bloemfontein, 9300. E-pos: versterp. hum@mail.uovs.ac.za 
rings van nader bekyk en dan nuwe voorstelle vir die betrokkenheid van die kerk aanbied.

\section{HISTORIESE OORSIG}

\section{$2.1 \mathrm{CCC}$}

Teen die helfte van die negentiende eeu het Livingstone (1813-1873) die suidelike en sentrale dele van Afrika deurkruis en aan Europa bekend gestel. Diep geskok oor veral slawerny en die gebrek aan infrastruktuur en ontwikkeling, het hy 'n beroep gedoen op die Christelike wêreld om by Afrika betrokke te raak. Hy het die bekende drie beginsels waarvolgens hierdie betrokkenheid kan plaasvind, vasgelê, naamlik "Christianity, civilisation, commerce" (Sanneh 1992:105, Ward 1999:213). Met hierdie sleutel wou hy Afrika ontsluit en die mense van Afrika deur die sending, maar ook deur middel van die "Christelike" beskawing, op 'n nuwe weg plaas (Moorhouse 1973: 131). Sy oproep aan kerke in Brittanje was juis om die groot seer in Afrika te kom genees (Cronjé 1981:11). Ludwig Krapf (1810-1881), wat ook in Afrika gewerk het, was skepties oor enige verbintenis met kolonialisme (Ward 1999:214). Hy het wel groot klem op sending gelê, maar was afwysend teenoor enige gedagte dat Europa sy beskermende hand oor die "donker" kontinent kon hou. Die ellende van Afrika sou volgens hom net deur die oorheersing van Europese magte verskuif word en nie weggeneem word nie (Ward 1999:214). Hy was dus van mening dat die sending veel eerder sy eie weg in Afrika moes vind en die unieke omstandighede van Afrika intern moes hanteer. Hier is dus reeds twee verskillende standpunte wat in 'n vroeë stadium na vore kom. Livingstone se ideale is egter tog — soms onwillig nagevolg (Hastings 1999:216).

Livingstone se bedoelings was waarskynlik suiwer (vgl. ook Du Plessis 1911:272-275), maar die gevolg van sy benadering was dat ontwikkeling en eksploitasie hand aan hand gegaan het. Sanneh (1992: 106) toon aan dat Livingstone groot klem gelê het op die beskawende invloed van Europa op Afrika, maar dat daar tog bewyse is dat hy byvoorbeeld die inheemse tale hoog geag het en dat dit juis sy stryd teen slawerny was wat hom beïnvloed het om aspekte van die kolonialisering van Afrika te bevorder. 
In this respect Livingstone was not only a representative figure of his age, he was in many ways its guiding light. He had delineated in broad outline the possible scope of colonial hegemony, but he also placed himself at the high frontier of Christian mission by anticipating the vernacular consequences of translation and their implications for Western cultural presuppositions (Sanneh:111).

Die Duitse Sendingwetenskap se latere beklemtoning van die volk of die sogenaamde "urtümliche Bindungen", waardeur die stamverband in ag geneem en hoog aangeslaan is, sou in 'n sekere sin by Krapf se standpunt aansluiting vind. Venn en Anderson (Beaver 1981:201) uit die Angel-Saksiese wêreld het die inheemswording van die kerk beklemtoon, maar die klem op die struktuur van die volk het uitgebly. Kamfer (1955:9) dui aan dat die "urtümliche Bindungen" by Gutmann iets goddeliks word. Die gevaar verbonde aan hierdie siening is groot, maar Hoekendijk (ca. 1953:273) se reaksie daarop het weer die positiewe interpretasie van volk, stam en gesinsverband onderwaardeer en sou tot die uitwissing van die Afrika-struktuur lei. Die samelewingsverbande van Afrika se strukture is afgebreek sonder dat dit deur die kerk ondervang is. Gutmann het juis die klem gelê op die gemeente as kreatiewe gemeenskap om die evangelie binne stamverband uit te dra en te bewaar (Kraemer 1956:339).

Glover (1960:249-255) dui aan dat daar inderdaad positiewe gevolge voortgevloei het uit Livingstone se ywerige werk in die kontinent wat deur sy tydgenoot Stanley as "donker Afrika" beskryf is. Die sterk teenkanting teen byvoorbeeld slawerny het vroeg reeds duidelik geblyk (Nunnenmacher 1995:88). Warneck (1910:279) dui ook aan dat die lewenskrag van die evangelie reeds sigbaar was in die Duitse sendingbediening in Afrika. Soos aangetoon, het die Duitse betrokkenheid in Afrika egter ook 'n ander benadering na vore laat kom (Gensichen 1961:38-39). Dit is dus duidelik dat die weë reeds hier skei tussen diegene wat van mening was dat Afrika, met al sy nood en ellende, op homself aangewese moet bly om binne sy eie raamwerk te ontwikkel en sy eie oplossings te soek, en diegene wat van mening was dat die kerk en die Westerse wêreld moet saamspan om ontwikkeling te inisieer — wat ook 'n totale ommekeer veronderstel het.

Die uiteenlopende standpunte van Krapf en Livingstone is dus verder gevoer. 


\subsection{Kolonialisme}

Aan die einde van die negentiende eeu het Europa se volledige kolonialisering van Afrika plaasgevind. Handel is sentraal gestel, asook die soektog na grondstowwe met gepaardgaande ontwikkeling. Koloniale regerings het wel op groot skaal infrastruktuur gevestig, maar dikwels vir eie gewin. Dit was die begin van verskeie krisisse in Afrika ten opsigte van aspekte soos die ekologie, mediese patologie, die ontwrigte gemeenskap en die inkorporering van tradisionele ekonomieë in die Europese kapitalistiese stelsel (Ward 1999:217).

Gensichen (1961:43) toon aan dat die Duitse kerke aanvanklik versigtig was vir vereenselwiging met die koloniale beleid, maar tog algaande meer betrokke geraak het by die gebiede onder die beskerming van die koloniale regerings. Die Christelike kerke het dit in baie opsigte as ' $n$ middel tot ' $n$ doel beskou - so sou die evangelie onder die beskerming van die koloniale owerhede tot heil van die gemeenskap uitgedra word. Die gevolge was egter in baie opsigte nie wat die kerk daarmee wou bereik het of daaronder verstaan het nie. Christelike opvoeding is wel as sentraal beskou (Ward 1999:218), maar daarteenoor is strukture afgebreek en die Christendom gelykgestel aan kolonialisme en die Westerse beskawing.

Sogenaamde tweede generasie-sendelinge het ook baie meer Westers gedink en hulle meer met die kolonialisme vereenselwig (www. African Christianity). Van den Berg (1956:144-147) toon juis aan hoedat die motiewe vir sending dikwels gekleur is deur die belange van die politiek. Van der Walt (2003:10) beskryf verskeie positiewe gevolge van kolonialisme, maar dui ook die vele negatiewe gevolge aan. Die negatiewe vooruitskouings van Krapf het dus nie uitgebly nie. Die dringende vraag bly dus steeds: Moes Afrika met rus gelaat gewees het om self al die probleme soos die plaaslike slawehandel en gebrek aan mediese dienste die hoof te bied, of moes die kerk inderdaad kolonialisme aangegryp het om Afrika volgens 'n Westerse model te ontwikkel?

Hier kom 'n verdere interpretasie van Livingstone se standpunt na vore wat by beide die Engelse en Duitse sendingaksies aangetref word, maar ook by ander Europese aksies, naamlik dat die helder Weste vir Donker Afrika moet verlig deur middel van kultuur, die Christe- 
like boodskap en die politiek. So word die kerk 'n middel tot 'n doel vir die politieke maghebbers, en die kerk laat hom dikwels meevoer deur hierdie proses.

\subsection{Uhuru}

Die opkoms van die politieke bevrydingsbewegings in Afrika, veral na die Tweede Wêreldoorlog, het die Uhuru-beweging tot stand laat kom. Dit was 'n poging om Afrika op politieke vlak volkome selfstandig te laat word. Reeds gedurende die koloniale tydperk het daar stemme opgegaan teen die uitbuiting van die plaaslike bevolking deur koloniale regerings (Ward 1999:226), maar die totale omwenteling was tog onverwags en radikaal. Daar was inderdaad besondere verwagtinge van die nuwe Afrika, en die kerkleier Gerdener (1964:17) het veral hoë verwagtinge van die opkomende leierskap van Afrika gekoester. Hastings (1967:102-116) skryf in 1967 dat daar besonder positiewe verwagtinge oor die dekolonisasie van Afrika en die politieke leiding van die Afrika-leiers is.

Afrika word toe wel bevry van kolonialisme, maar die ineenstorting van die politieke, ekonomiese en sosiale strukture volg. In sommige gevalle sluit die kerk volledig aan by die verpolitisering van teologie met die wanhoop waartoe dit lei, of vlug terug in evangelikaliese ontkenning.

Soek eers die politieke koninkryk, was die uitgangspunt van die politieke leiers van Afrika (Ward 1999:228-229). Verskeie kerkleiers en sendelinge moes met hulle lewens boet vir die opkoms van die politieke koninkryk in Afrika (Donovan 2000:177), en totale ontnugtering het gevolg na die mislukking van talle projekte. Diktators het eenvoudig finansiële besluite geneem en hulle koffers gevul so ook militêre en ander regerings (Van der Walt 2003:44-45).

Ward (1999:229) beskryf egter hoe die kerk wel hoop lewend gehou het onder die omstandighede:

In the decades after independence, as African states passed through various social, political and economic crises, resulting in army rule or an increasing breakdown of law and order, the Church often proved remarkably resilient both in an institutional sense and as a moral and spiritual focus of hope, in situations where it did not, in fact, make sense to "seek first" the political kingdom. 
Dat die bevryding van Afrika nie net positief was nie, word ook deur Van der Walt (2003:32) aangetoon, maar hy wys tog ook daarop dat die proses van kolonialisme dikwels die oorsaak was van die mislukking van die bevrydingsproses.

Die kerk se verwagting dat die politieke omwenteling groot heil vir Afrika sou inhou, het nie gerealiseer nie. Die standpunt dat die kerk vanuit Afrika polities betrokke moet raak, word dus verkeerd bewys in die sin dat die verwagte resultate nie bereik is nie.

\title{
2.4 Ontwikkeling
}

'n Nuwe benadering deur nuwe leiers van Afrika asook Westerse leiers, was nou nodig om Afrika van toenemende ellende te red. Verskeie kerke sluit in hulle verkondiging aan by die ontwikkelingsgedagte en wil die Weste daartoe lei om te deel in die ontwikkeling van Afrika en sodoende die mense op te hef. Groot insette word gelewer, maar in plaas van totale ontwikkeling volg dikwels toenemende ellende. Dit lei tot apatie in die Weste, gevolg deur Afro-pessimisme. Die kerk vra selfondersoek van die Weste, maar min nuwe aksies word onderneem.

Sommiges beskou die inisiatief van NEPAD en die Afrika Renaissance inderdaad as 'n hoopvolle nuwe rigting. Deur die erkenning van die betekenisvolle eie bydrae van Afrika word gepoog om hierdie kontinent tog ook in die globale wêreld tuis te laat kom. Dit vereis realisme, maar ook optimisme. Guèye (1999:236) skryf soos volg:

\begin{abstract}
While continents like Europe or America, which could have good reasons for considering themselves as strong enough to survive and prosper on their own, are doing their best to unify, Africa is still wasting its precious time, energies, resources and capacities in bloody internal conflicts which cannot be excused only by blaming former colonialism and its famous "divide and rule" approach, or the inter-imperialist contradictions. We do not deny that they exist, but we believe that they can operate only because there are Africans who are ready to be their instruments. So let us stop the comfortable but infantile attitude of always blaming others for our irresponsibility and inability to face the objective demands of the historical situation of our continent.
\end{abstract}

Die rol van die kerk sal dus opnuut beoordeel moet word. Livingstone se positiewe oordeel oor Europese betrokkenheid het ook sy 
mislukkings gehad, Krapf se standpunt dat Afrika alleen gelaat moet word, het soms op ontduiking van verantwoordelikheid gedui, en die politieke betrokkenheid het ook misluk. Die gevaar is inderdaad groot dat kritieklose steun vir die NEPAD-inisiatief weereens op mislukking sal uitloop. Daar moet dus 'n ander weg gesoek word.

\section{DIE HUIDIGE AFRIKA}

Die huidige Afrika gaan gebuk onder ernstige probleme en bedreiginge. Telkemale wanneer daar met groot optimisme nuwe verwagtinge geskep word, word die optimisme weer getemper deur harde werklikhede. Van Niekerk (2002:120) dui onder andere die volgende probleme aan:

- Hoë bevolkingsgroei;

- Hoë voorkoms van HIV/Vigs en ander siektes soos malaria en cholera;

- Streeksoorloë;

- Ineenstorting van state;

- Agteruitgang van natuurlike hulpbronne;

- Verminderende Westerse betrokkenheid.

Hierby sluit Van der Walt (2003:39-54) aan deur te wys ook op sake soos:

- Sosiale ellendes soos honger, siekte, dehumanisering, ensovoorts;

- Ekonomiese krisisse;

- Politieke rampe, veral onbuigsame eenpartystate en militêre regerings en die gebrek aan leierskap en regering;

- Die ongunstige beheer van Afrika deur internasionale ekonomiese stelsels;

- Krisisse in onderwys en moraliteit.

Ook Nürnberger (2003:499) verwys na die besonder groot en diepgewortelde nood in Afrika suid van die Sahara, wat ' $n$ buitengewone benadering vereis. Volgens hom is ekonomiese agteruitgang steeds nie volledig gestuit nie (Nürnberger 2003:505). Beukes (2002: 106) toon op sy beurt aan dat Suid-Afrika self deur ernstige probleme in die gesig gestaar word: 
There is an overwhelming feeling that South Africa has to move rapidly to eliminate poverty, or our political "miracle" will come under siege, the moral basis of our state will be imperilled and our democracy itself will characterise our future. There seems to be a mood of moral outrage as well as anxiety.

en:

For the more than $50 \%$ of the population of South Africa who are struggling to survive below the official poverty line, life in South Africa is not easy, to say the least. If they were able to find the time and energy to formulate the question amidst their daily struggle, they would probably say that the question for them is not so much if God really cares, but how they can experience it. Christian Aid in the UK shows the way with the slogan "We believe in life before death".

Die verwagtinge wat NEPAD skep, is dus 'n tydige boodskap om juis in Afrika vanuit Afrika vernuwing te bring.

\section{VOORSTELLE VIR DIE NUWE AFRIKA - HEIL IN AFRIKA}

Daar is tekens van nuwe hoop in Afrika. Die kerk se rol is nie altyd duidelik uitgespel nie. Die wesenlike vrae wat die kerk moet vra, moet aangedui word. Is die ondersteuning van globalisering nie bloot die Livingstone-standpunt wat in nuwe gedaante kritiekloos toegepas word nie? Is die groot teenkanting daarteen nie dikwels 'n soort Afrikavolksteologie soos in Zimbabwe nie? Vervolgens moet hierdie standpunte ontleed word.

\subsection{Revolusionêre verandering en demokratisering}

Die Uhuru-opvatting word soms voorgehou as die antwoord op die huidige probleme van Afrika. Ten eerste kan verwys word na diegene wat meen dat die kerk in Afrika betrokke moet wees by die revolusionêre oorgang van een bestel na 'n ander om Afrika so weer op koers te plaas. Hierdie vorm van bemagtiging het vergestalting gevind in die bevrydingsbewegings van die sestigerjare. Later is die bevrydingsbewegings in 'n sekere mate gedemokratiseer en is gemeen dat die kerk die demokratiseringsproses moet help voltooi. Die kerk het dus 'n rol gespeel in die legitimering en erkenning van die bevrydingsbewegings. 
Die gevolge van hierdie bydrae is nie altyd positief nie, aangesien die kerk dikwels as instrument in die bevrydingsbeweging gebruik word. Dit lei nie altyd tot ontwikkeling of demokratisering nie. In die praktyk gebeur dit dikwels dat die kerk sigself onderwerp aan 'n gewelddadige bestel. Die kerk probeer dan regverdiging vir sy bestaan kry deur vereenselwiging met die gewelddadigheid van vorige of huidige bevrydingsbewegings en dus ook met die beginsel dat die doel die middele heilig.

Mugambi (1997:34) stel voor dat die kerk wel by die politiek betrokke moet wees, maar dan in 'n leierskapsrol:

The Church, as a utopian community, is not of the world, but as a so-
cial reality, it is in the world. Therefore, Christians as citizens cannot
avoid involvement in the political, economic and moral challenges
facing their communities. At best, they ought to be providing exem-
plary leadership. They should be to their communities as salt in
food and light in the world. In order to fulfil this role, the Church
itself will require internal re-structuring. At the core of Christian
faith is the hope that the Church will exercise the capacity and the
potential for this internal renewal. (Kursivering Mugambi.)

Die oorgang is egter nie altyd maklik nie en moet ook deur die kerk bestuur word.

Nürnberger (1990:218) wil juis die vertikale dimensie verhorisontaliseer. Hy (2003:517-518) wil vernuwing op die volgende terreine in die lig van Luther se teologie beklemtoon:

- Geloof en verantwoordelikheid hang saam;

- Die wet van God, in die lig van Luther se begrip daarvan, is nie arbitrêr nie, maar 'n voorwaarde vir 'n gesonde gemeenskap;

- Die vrye genade van God beklemtoon dat die swakke en die uitgeworpene juis in die kerk aanvaar moet word; en

- Transformasie moet as vrug van die Gees bereik word.

Die openbare verantwoordelikheid van die kerk moet deur kerkleiers in hul profetiese bediening nagekom word, die gemeente moet getuig in die gemeenskap en alle lidmate moet getuies vir God se saak in hul sekulêre en daaglikse lewe wees.

Nürnberger (1999:444) wys daarop dat die totale gemeenskap ondersteun moet word: 
On the other hand, the skills and means of the peripheral population can be enhanced deliberately. Here the state, the private sector, the church, the scientific community and the NGOs can all cooperate to overcome poverty. The goals should be to level the playing field; release local initiatives; provide access to resources; build up skills; facilitate networking; create the environment for micro and small businesses, and nurture the disempowered until they are competitive.

The marginalised must have the constitutional right to be represented on all decision making bodies, including larger enterprises, unions, government departments, and local authorities. Municipal or state services can be transferred to community responsibility. Potential initiators and leaders among the population can be identified, trained and given opportunities to gain experience.

Kritzinger (Klippies) (1995:394) is van mening dat die deurslaggewende toets vir 'n godsdienstige gemeenskap die betrokkenheid daarvan by geregtigheid, voedselverskaffing vir armes, die bevryding van selfverwoestende gewoontes en negatiewe selfbeelde, en die bewaring van die aarde is. So kan Afrika herrys (mayibuye iAfrika).

Bosch (1979:244) gaan ook van die standpunt uit dat die kerk transformasie moet teweegbring. Die sending is by die wêreld betrokke nie om mense te roep om in die kerk liedere te sing nie, maar juis om mee te werk aan die transformasie van die wêreld waarin hulle woon.

Daarom wil Beukes (2002:117) juis die hoop beklemtoon (THEMBA):

The search for an alternative to what the poor and the excluded are experiencing, which brings the biblical concepts of justice and liberation within the reach of the unemployed and the working poor in South Africa, in Africa and in the rest of the world.

Die dringende vraag is of die kerk hiermee nie — soos wat dikwels gebeur het - sy wesenlike roeping versaak en diensbaar word aan politieke modelle nie.

\subsection{Voortgesette ontwikkeling}

Ontwikkelingsdenke het 'n uiters belangrike rol in Afrika gespeel. Van der Walt (2002:450) wil vanuit gereformeerde hoek nuwe betekenis hieraan gee:

My definition reads as follows: Development is the (1) balanced unfolding of (2) all the abilities of the human being and (3) the potential of material things, plants and animals (4) according to God's purpose and (5) his will, to enable the human being (6) within his/her own 
culture, (7) to fulfil his/her own calling (8) as a responsible steward of creation (9) in a free society (10) to the honour and glory of God.

Hy is egter van mening dat geen ontwikkeling - insluitende ekonomiese en politieke ontwikkeling — gesond van aard kan wees sonder 'n deeglik gefundeerde lewensvisie nie. Die klakkelose aanvaarding van die Westerse model hou volgens hom geen heil vir Afrika in nie:

Development can only be genuine development - enhancing the well-being of the whole human being and not only his/her material welfare - when it seriously takes into account the culture, worldview and religion of the people to be "developed." Only to our detriment can we ignore the fact that Africa is not identical to the West and therefore needs its own indigenous way of development (Van der Walt 2002:507).

Daarom wil hy beklemtoon dat Afrika beheer van sy eie toekoms moet neem en dat 'n lewenskragtige visie ontwerp moet word om die koninkryk van God in gehoorsaamheid aan die hele wil van God te vestig (Van der Walt 2003:58). Die tradisie van Afrika moet nie uitgesluit word nie, maar juis in ag geneem word wanneer so 'n vernuwende Christelike lewens- en wêreldvisie beplan word (Van der Walt 2003b:67). Dis 'n goeie vraag of Van der Walt in dieselfde slaggat as Livingstone trap: die lewensvisie is wel Christelik, maar die fundering van die voorgestelde ontwikkeling is Westers-georiënteerd.

Swart (2003:424) wys op die gevare van ontwikkelingsdenke en verwoord die volgende perspektief:

They imply that the churches, whether in Africa, the rest of the socalled developing world or the developed world, have arrived at the cross-roads regarding their concern with development. Indeed, part of the churches' call in development will always be to take care of the immediate needs of the poor and deprived. But they are today also summoned to move on to more authentic modes of engagement - authentic in terms of their own unique institutional and vocational nature, authentic also in terms of the essential problems of development. In the perspective of the pragmatic debate and what has been further formulated in this paper, for the churches such authentic involvement can only point in one direction: a new concern with spiritual renewal, a conscientisation of the rich, a clear political option for the poor, a new embracement of sustainable values and modes of living, resistance to the current world system and its institutions of power, a new solidarity relationship with actors from the NGOs and new social movements. (Kursivering Swart.) 
Die kerk moet egter poog om 'n eie selfstandigheid aan ontwikkeling te gee. Die missionêre diakonaat omvat nie die hele sending nie.

\subsection{Volg die Gekruisigde en gee mag prys}

'n Derde moontlikheid is dat die kerk deur die sending die maghebbers moet lei om mag prys te gee. Bram van de Beek (2003:207) stel voor dat die Christen in sy/haar sending in die wêreld mense moet lei tot by die punt waar hulle mag en heerskappy prysgee om erkenning aan God se totale gesag te gee. In Afrika sou dit beteken dat die teenoorgestelde proses gevolg moet word as die een waarin mag vooropgestel word. Die kerk se taak sal dan wees om mense as't ware te ontmagtig sodat hulle hul volledig kan oorgee aan Jesus Christus, die Gekruisigde. So word daar dan in diens van 'n ander wêreld opgetree om die koningskap in hierdie wêreld af te wys; 'n nuwe bestaan word nagestreef waarin die verskrikkinge en die uitbuiting van mag prysgegee word.

Die kerk moet inderdaad onmagtig word en die sending, soos Paulus, in gebrokenheid beoefen. In die sending reik die kerk in diens van die lewende Christus uit na die ryk van God.

\subsection{Vestig die grondstrukture van die gemeente en gesin}

'n Vierde moontlikheid is dat die kerk deur die bediening van die Woord in die gemeentes in Afrika sal poog om grondstrukture te vestig. Die gemeente self word dan die punt waar hierdie grondstrukture gevestig word en waar 'n gemeenskaplike grondslag gevind word. Met hierdie gemeenskaplike grondslag en grondstrukture van die gemeente as vertrekpunt word daar dan in die gemeenskap gewerk.

Van Niekerk (2002:123) stel voor dat in plaas daarvan om opnuut na 'n bevrydingstelsel te soek om weer 'n demokratiseringsproses aan die gang te sit, die kerk liewers daarna moet strewe om op grondvlak by gesinne betrokke te raak. Deur die gesin te bemagtig, kan vernuwing in Afrika gebring word. Die gesinstruktuur, wat 'n hegte eenheid behoort te vorm, kan so bemagtig word dat die hele gemeenskap daarby baat vind.

Die kerk se groot taak sal wees om by die gesinne in die gemeenskap uit te kom. Om hierdie gesinne te help, sal die kerk besondere 
aandag aan hulle moet gee deur die bediening van die Woord. Die wyse waarop gesinne bemagtig word, is juis deur verskillende elemente van gesinne te betrek by kerklike aktiwiteite. Dit sluit aan by die tradisionele Afrika-gemeenskap waar die hegtheid van die gesinsgemeenskap sowel as die stamgemeenskap besonder hoog geag word. Van Niekerk (2002:123) stel die saak soos volg:

It is the household and family that must be re-established and strengthened if we wish to combat poverty and become a prosperous, growing and peaceful region. A local congregation can make a meaningful contribution against poverty and need if it can help to strengthen the family structures of poverty-stricken families, whether they are Christian or non-Christian.

Mulundi-Nyanga (1997:75) beklemtoon ook die grondstrukture van die samelewing:

Being children of God, African Christians must see their tribes and ethnic groups as special covenants defined as relationships of entrusting and accepting entrustment that have arisen out of some special historical transaction among the members - and not only from their participation in the inclusive covenant.

Dit is moontlik om hierin weer die stem van Krapf te hoor, met 'n nuwe beklemtoning van die hoop wat die evangelie op grondvlak bring.

\subsection{Equitas}

'n Verdere moontlikheid is om aansluiting te vind by die equitasgedagte van Calvyn soos deur Bram van de Beek voorgestel. Calvyn (sd:558 e.v.) se gedagte was dat daar in 'n samelewing veral deur die owerheid na balans gestreef moet word. Mense is inderdaad nie gelyk nie; dit weet almal. Daar bestaan nie iets soos absolute gelykheid tussen mense nie. Wat wel deur die owerheid bevorder moet word, is equitas: gelykheid in die sin dat mense die volle geleentheid moet kry om hulself uit te leef sonder om onderdruk te word - hulle moet in 'n bepaalde verhouding van balans lewe. Hierdie equitas beteken dat die owerheid daarna sal strewe om te sorg dat sommige in die gemeenskap nie uitgebuit word nie en dat ander nie uitermate ryk word nie.

Wat ook onthou moet word, is dat Calvyn die ongedifferensieerde Christelike gemeenskap in die oog het en nie die godsdienstig en kul- 
tureel gedifferensieerde demokratiese staat nie. Onder Westerse demokrasieë is die gevaar van individualisme byvoorbeeld baie groot (Kritzinger 2000:113).

Sommige is van mening dat die Christelike politieke party die saak van demokrasie die beste kan dien en dat kerke so moet saamstaan (Omenka 2003:368). Die steun van evangeliese groepe in Suid-Afrika vir die ACDP dui egter op 'n onkritiese toepassing van dié standpunt. Die naam "Christelike party" is nie 'n waarborg vir ware Christelike regering nie. Verwagtinge dat Christenleiers noodwendig vernuwing sou bring (Phiri 2003:426), het ook nie altyd gerealiseer nie.

\section{DIE SENDING IN AFRIKA: VERLORE SAAK OF UITDAGING?}

Daar moet geen twyfel bestaan dat die oomblik wanneer die sending sy primêre betrokkenheid by die evangelie van Jesus Christus en die oproep van die apostel Paulus, "Laat julle tog met God versoen", verloor, dit sy wesenlike rol prysgee nie. Wanneer die sending - met die kragtige getuienis vanuit die Woord van God dat Jesus die Here is - in Afrika steeds bevestig dat God ingryp en heil bring, sal die vrugte daarvan sonder twyfel gepluk word.

Die gedagte van verbondenheid aan God sal deur die kerk, maar ook in gesinsverband, beklemtoon moet word. Volgens Shenk (2001: 105) moet die teologie self die kerk ondersteun in getuienis en diens aan die wêreld. Daar moet weer uit die lewe van die vroeë kerk geleer word. In hierdie opsig is daar geweldig baie wat in Afrika gedoen kan word. Dit is 'n kontinent waarin gesinne uitmekaar geruk is en waarin die gemeenskapsverband verbreek is. Alhoewel daar baie Christene is wat kritiek uitspreek teen die gedagte dat dié hegte eenhede behoue moet bly, onder andere J.C. Hoekendijk (ca 1953:269-277), is daar tog na vele jare van nadenke en herbesinning beklemtoon dat die gesinsverband en gemeenskapsverband in ag geneem moet word.

Hoe kan die kerk juis die gesinne opbou in Afrika? In hierdie verband kan baie sterk by Attie van Niekerk aansluiting gevind word en moet die gedagte dat die kerk op grondvlak die opbouwerk kan doen, lewend gehou word. Dit is tans baie duidelik dat Afrika nie 'n blitssnelle transformasie sal kan ondergaan om die vlak van Westerse 
lande, wat reeds ontwikkeld en gedemokratiseer is, te bereik nie. Daar sal dus 'n baie langsame proses moet wees waarin die kerk 'n nederige gestalte aanneem om mense opnuut na Jesus Christus te bring. Waar mense in afhanklikheid van Christus lewe, gebonde aan die Here Jesus, en met 'n roeping in die wêreld om binne gesins- en gemeenskapsverband die Naam van die Here groot te maak, kan positiewe gevolge kom. Dat evangeliese sending dikwels duidelike positiewe gevolge op die politieke terrein het, word deur Hearn (2002:56) aangedui. Somé (2001:301) toon egter aan dat die "Christian base communities", wat met soveel verwagting as politieke instrumente beskou is, nie altyd 'n gesonde invloed uitgeoefen het nie.

Die Duitse Sendingwetenskap het in hierdie verband wel sekere belangrike aspekte raakgesien, al was dit dan ook op 'n gebrekkige wyse. Hulle het byvoorbeeld uitgegaan van die standpunt dat die gesins- en stamverband nie vernietig moet word as jy mense in Afrika wil opbou nie. Die kerk sal sy profetiese rol vervul deur mense aan te moedig om onderlinge respek vir mekaar te openbaar, maar die kerk sal ook ' $n$ baie meer evangeliese rol moet speel deur mense so te bemagtig dat hulle as 'n gemeenskap van gelowiges wat aan God behoort, 'n konstruktiewe bydrae tot die samelewing kan lewer (vgl. Van Wyk 2000:69). Dit mag moontlik wees dat 'n soort evangelikalisme soms geld, wat inderdaad afgewys moet word, maar 'n evangeliesgereformeerde beskouing waarin die heerlikheid van God beklemtoon word, is inderdaad noodsaaklik.

Wat die politiek betref, sal die kerk nooit kan optree asof alle wetenskaplike kennis oor regering in sy hand is nie. Daar sal wel die profetiese stem teen onreg wees, maar ook die erkenning dat die kerk nie op wetenskaplike vlak die beste politieke bestel uit die Bybel kan aflei nie — die omstandighede moet in ag geneem word. Lidmate, d.w.s. die kerk op grondvlak, sal veral as Christen politieke wetenskaplikes 'n bydrae op hierdie vlak kan lewer. Op die makro-vlak van die politiek en ekonomie kan die kerk nie veel meer vermag as om die rolspelers op te roep tot geregtigheid en onderlinge samewerking nie. So kan die beste vir die mense beding word.

Du Plessis (1929:354-355) vra in 1929 of die lot wat die sending sal tref dieselfde as die van die Rooms-Katolieke sending in die $16^{\text {de }}$ 
en $17^{\text {de }}$ eeu sal wees. Hy vra of die sending in Afrika op dieselfde wyse sal kwyn. Sy antwoord is "nee" en die rede wat hy gee, is dat die krag van die sending en die hoop vir Afrika in God lê.

\section{BIBLIOGRAFIE}

\section{BEAVER R P}

1981. The history of mission strategy. In: R. Winter \& S.C. Hawthorne (eds.), Perspectives on the world Christian movement: a reader (Pasadena, Ca.: William Carey), pp. 191-205.

\section{Beukes $\mathrm{P}$}

2002. Life before death — Socio-economic justice issues and mission: the economy, poverty and the church. In: D. Kritzinger (ed.), No quick fixes: challenges to Mission in a changing South Africa (Pretoria: Universiteit van Pretoria. Instituut vir Missiologiese en Ekumeniese Navorsing), pp. 103-117.

\section{Bosch D J}

1979. Heil vir die wêreld: die Christelike sending in teologiese perspektief. Pretoria: NG Kerkboekhandel.

\section{CALVIJN J}

[s.a.] Institutie of onderwijzing in de Christelijke godsdienst. (Vert. A. Sizoo). Deel 3. Delft: Meinema.

\section{Cronjé J M}

1981. Aan God die dank. Geskiedenis van die sending van die Ned. Geref. Kerk. Deel

2: Buite die Republiek van Suid-Afrika. Pretoria: NG Kerkboekhandel.

\section{De KLeRK C}

1923. Kerk en sending in Suid-Afrika. Akademiese proefskrif. Amsterdam: Bottenburg.

\section{DONOVAN V J}

2000. Christianity rediscovered: an epistle from the Masai. Londen: SCM.

\section{Du Plessis J}

1911. A bistory of Christian missions in South Africa. Londen: Longmans, Green \& Co.

1929. The evangelisation of pagan A frica. Kaapstad: Juta. 


\section{GENSICHEN H W}

1961. Missionsgeschichte der neueren Zeit. Göttingen: Van den Hoeck \& Ruprecht.

\section{Gerdener G B A}

1964. Ons taak in die nuwe Afrika. Elsiesrivier: Nasionale Handelsdrukkery.

\section{GLOVER R H}

1960. The progress of world wide missions (revised an enlarged by J. Herbert Kane).

Londen: Harper \& Row.

\section{GUÈYE S P}

1999. African Renaissance as an historical challenge. In: M.W. Makgoba (ed.), African Renaissance. Kaapstad: Mafube.

\section{HAsTings A}

1967. Church and mission in modern Africa. Londen: Burns \& Oates.

\section{HEARN J}

2002. The "invisible" NGO: US Evangelical missions in Kenya. Journal of Religion in Africa 32(1):32-57.

\section{HoeKendijK J C}

[c. 1953.] Kerk en volk in de Duitse zendingwetenschap. [s.1.:s.n.].

\section{KAMFER P P A}

1955. Die volkorganiese sendingmetode by Bruno Gutmann. Akademiese proefskrif. Amsterdam: Swets \& Zeitlinger.

\section{KRAEMER H}

1956. The Christian message in a non-Christian world. 3rd ed. Grand Rapids, Mich.: Kregel.

\section{KRITZINGER J J}

2000. Mission in the new South Africa: need for a renewed enquiry. Skrif en Kerk 21(1):93-114.

\section{KRITZINGER J N J}

1995. Studying religious communities as agents of change: an agenda for missiology. Missionalia 23(3):366-396.

\section{MoOrhouse G}

1973. The missionaries. London: Eyre Methuen.

\section{Mugambi J N K}

1997. African churches in social transformation. In: J.N.K. Mugambi (ed.), Democracy and development in Africa: the role of churches (Nairobi: All Africa Conference of Churches).

\section{MULLER K \& USTHORF W}

1995. Einleitung in die Missionsgeschichte: Tradition, Situation und Dynamik des Christentums. Stuttgart: Kohlhammer. 


\section{Mulundi-NyANGA N D}

1997. The reconstruction of A frica: faith and freedom for a conflicted continent. Nairobi: All Africa Conference of Churches.

\section{NÜRNBERGER K}

2003. God's mission in practice: the struggle for liberation, dignity and justice in African societies. International Review of Mission 92(367):498-520.

1990. Salvation or liberation: The soteriological roots of a missionary theology. Missionalia 18(1):205-219.

1999. Prosperity, poverty and pollution: managing the approaching crisis. Pietermaritzburg: Cluster.

\section{TSELE M}

1997. Theses on economic justice: Towards an economy of life. In: M. Guma \& L. Milton (eds.), An African challenge to the church in the $21^{\text {st }}$ century (Kaapstad: Inner City Mission).

NunNENMACHER E 1995. Schwarzafrika — Die katholische Erfahrung. In: K. Muller \& W. Usthorf (Hrsg.), Einleitung in die Missionsgeschichte: Tradition, Situation und Dynamik des Christentums (Stuttgart: Kohlhammer), pp. 82-98.

\section{OMENKA N I}

2003. Christian missions and the training for political leadership in Eastern Nigeria. International Review of Mission 92(366):356-369.

\section{PHIRI I A}

2003. President Frederick J.T. Chiluba of Zambia: the Christian nation and democracy. Journal of Religion in Africa 33(4):401-427.

\section{SANNEH L}

1992. Translating the message: the missionary impact on culture. N.Y. Maryknoll: Orbis Books.

\section{SHENK W R}

2001. Recasting theology of mission: impulses from the non-Western world. International Bulletin of Missionary Research 25(3):98-106.

\section{SOMÉ M}

2001. Christian base communities in Burkino Faso: between church and politics. Journal of Religion in Africa 31(3):275-302.

\section{SWART I}

2003. Church, mission and development. Revisiting the pragmatic debate. Missionalia 31(3):405-426.

\section{VAN DE BEEK A}

2003. De Here is één. Gereformeerde Theologische Tijdschrift 103(1):197-208. 


\section{VAN DEN BERG J}

1956. Constrained by Jesus' love: an inquiry into the motives of the missionary awakening in Great Britain in the period between 1698 and 1815. Proefskrif. Kampen: Kok.

\section{VAN DER WALT B J}

2003a. Understanding and rebuilding Africa. Potchefstroom: [Eie uitgewer].

2003b. Morality in Africa: yesterday and today. The reasons for the contemporary crisis. In die Skriflig 37(1):51-72.

\section{VAN NiEKERK A}

2002. A strategy against poverty in South Africa. In: D. Kritzinger, (ed.) No quick fixes: challenges to mission in a changing South Africa (Pretoria: Universiteit van Pretoria; Instituut vir Missiologiese en Ekumeniese Navorsing), pp. 119-128.

\section{VAN WYK J H}

2000. Vryheid as tema van die sosiale etiek (in Suid-Afrikaanse konteks). In die Skriflig 34(1):55-82.

\section{WARD K}

1999. Africa. In: A. Hastings (ed.), A world history of Christianity (Londen: Cassell), pp. 193-237.

\section{WARNECK G}

1910. Ubriss einer Geschichte der protestantischen Missionen von der Reformation bis auf die Gegenwart, mit einem Unhang über die katolischen Missionen. Berlin: Warned.

www.bethel.edu/ letnie/AfricanChristainity/SSAColonialProtestant.html.

Trefwoorde

Ontwikkeling

Sending

Afrika

Familie
Keywords

Development

Mission

Africa

Family 